\title{
ASSESSING SOUTH-SOUTH REGIONAL INTEGRATION: SAME ISSUES, MANY METRICS
}

$$
\text { by }
$$

\section{Lucian Cernat}

\section{Associate Economic Affairs Officer}

Trade Analysis Branch

Division on International Trade in Goods and Services, and Commodities United Nations Conference on Trade and Development

Geneva, Switzerland

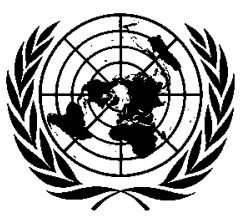

UNITED NATIONS

New York and Geneva, 2003 


\section{NOTE}

The views expressed in this study are those of the author and do not necessarily reflect the views of the United Nations.

The designations employed and the presentation of the material do not imply the expression of any opinion whatsoever on the part of the United Nations Secretariat concerning the legal status of any country, territory, city or area, or of its authorities, or concerning the delimitation of its frontiers or boundaries.

Material in this publication may be freely quoted or reprinted, but acknowledgement is requested, together with a reference to the document number. A copy of the publication containing the quotation or reprint should be sent to the UNCTAD secretariat:

\section{Chief}

Trade Analysis Branch

Division on International Trade in Goods and Services, and Commodities United Nations Conference on Trade and Development

Palais des Nations

CH-1211 Geneva

$\mathrm{UNCTAD/ITCD/TAB/22}$

\begin{tabular}{|c|}
\hline UNITED NATIONS PUBLICATION \\
\hline Sales No. E.02.II.D.11 \\
\hline ISBN 92-1-112559-6 \\
\hline ISSN 1607-8291 \\
\hline
\end{tabular}

C) Copyright United Nations 2003

All rights reserved 


\begin{abstract}
Not only has the number of RTAs increased over time, but so also has the complexity of issues surrounding their formation, as well as the metrics used to assess them. Despite sustained research efforts, and irrespective of the approach adopted, the economic merits or demerits of regional integration arrangements remain essentially an empirical matter. Given the importance of this issue and the ambiguity that persists with regard to the economic impact of many RTAs among developing countries, the present paper uses a gravity model to analyse ex post the trade effects of seven South-South RTAs (AFTA, Andean Community, CARICOM, COMESA, ECOWAS, MERCOSUR, SADC), and a CGE model for an ex-ante analysis of a Framework Agreement on Trade Preferential System (FATPS) among the member States of the Organization of the Islamic Conference.

The gravity results have shown that with the exception of the Andean Community and MERCOSUR, which seemed to have reduced trade with non-members, the other South-South RTAs examined are not only trade-creating but also trade-expanding, increasing overall trade, even with third countries, sometimes quite significantly. In the case of FATPS, the ex-ante static CGE results suggest that, despite some potential for trade diversion, the net effect is trade creation.
\end{abstract}




\section{ACKNOWLEDGEMENTS}

The author would like to thank Sam Laird and Alessandro Turrini for their helpful insights, and the participants in the seminar on the Framework Agreement on Trade Preferential System Among Islamic Countries (Istanbul, 19 October 2001) for their comments on an earlier version of this paper. 


\section{CONTENTS}

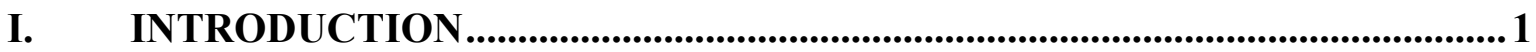

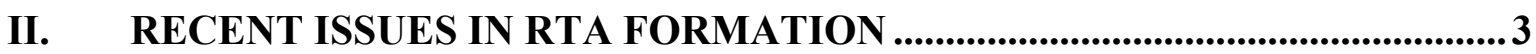

III. METHODOLOGICAL APPROACHES TO

THE STUDY OF RTA TRADE EFFECTS ............................................................7

A. South-South RTAs: A gravity model-based ex-post assessment..................... 7

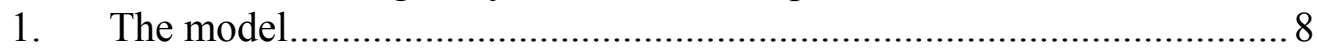

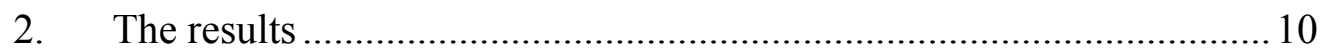

B. Ex-ante CGE analysis: assessing the impact of the FATPS .......................... 10

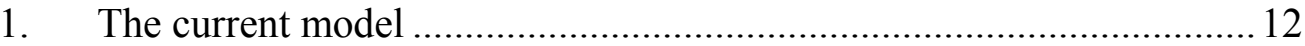

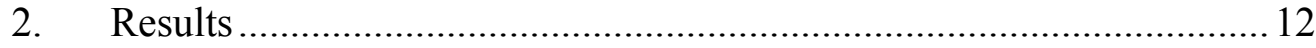

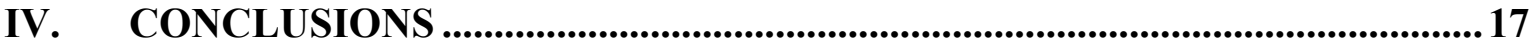

NOTES

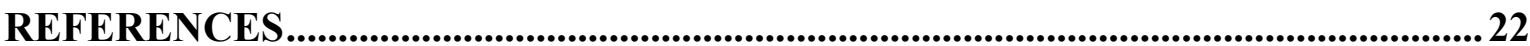




\section{Tables}

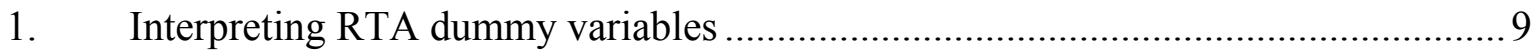

2. Full FATPS-OIC scenario: percentage changes in selected variables..................... 13

\section{Figures}

1. Number of notified RTAs, by year of entry into force .......................................... 3

2. Classifying RTAs at various stages of negotiation or implementation during 2001

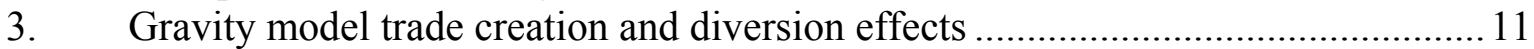

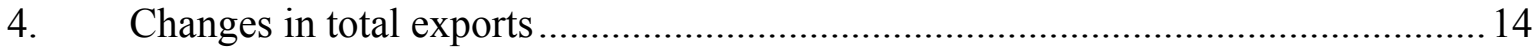

5. Full FATPS liberalization: percentage changes in sectoral exports ....................... 15

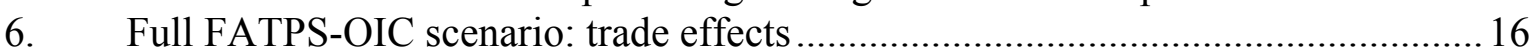

\section{Box}

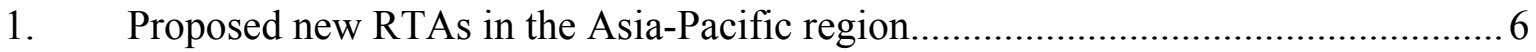

\section{Annexes}

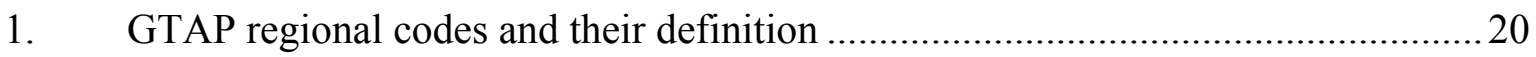

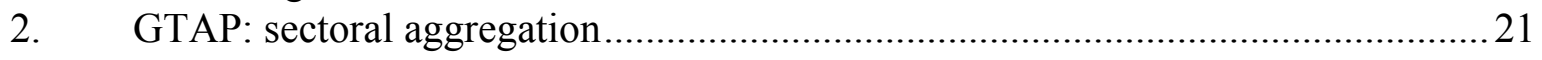




\section{INTRODUCTION}

In the late 1980 s and early 1990 s, in parallel with the GATT negotiations under the Uruguay Round, many countries entered into trade negotiations aimed at the formation, revitalization or extension of regional trade agreements (RTAs). Some developed countries consolidated their existing regional integration mechanisms, moving towards even deeper integration, for example the European Union (EU) Single Market, established in 1992. Other country groups created new RTAs or are currently involved in RTA formation. Recently, new RTAs have been initiated by countries that had traditionally been the main proponents of the multilateral approach under GATT (Japan, the Republic of Korea, Singapore and other countries in East Asia).

Not only has the number of RTAs increased over time, but so also has the complexity of issues surrounding their formation, as well as the metrics used to assess them. Given this renewed interest in RTAs, many policy-makers and academics have been questioning the impact of RTAs on participants and third countries. ${ }^{1}$ For policy-makers, RTAs represent a solution to a multitude of issues: accelerating and locking in domestic reforms, positive political and economic spillovers at regional level, a relatively controlled learning process for liberalization, increased market access for domestic industries, a more prominent role on the international scene through partnership within an RTA, and so forth. Moreover, as RTAs are being formed among other trade partners, they are increasingly seen as a form of defence against trade diversion.
Among some academics, the quest seemed to have been more about finding the most popular catchphrase to describe the complex process of regionalism. Jagdish Bhagwati referred to the process of RTA proliferation whereby countries become interconnected in a myriad of overlapping RTAs, as the "spaghetti bowl" phenomenon (Bhagwati and Panagariya, 1996). ${ }^{2}$ Another expression that has had a long career is the hub-and-spokes concept (Wonnacott, 1990). ${ }^{3}$ Most of the debate stemming from this approach to regionalism was centred on the building vs. stumbling blocks effect, ${ }^{4}$ which was also a popular reference in the RTA debate. ${ }^{5}$ Yet another concept put forward to explain this time the surge in RTA formation is the "domino theory"" (Baldwin, 1993).

Apart from these attempts at conceptual clarifications and grand theories focused on producing a generally accepted, "one-size-fits-all" explanation of the existing RTAs, more modest attempts concentrated on the diversity of recent RTAs in terms of membership and scope, and looked at specific issues such as the elimination of nontariff measures (NTMs), technical barriers to trade (TBTs), beyond-the-border measures, standards, competition policies, environment, anti-dumping and investment. Despite these sustained research efforts, and irrespective of the approach adopted, the economic merits or demerits of regional integration arrangements are essentially an empirical matter (Viner, 1950), but political and strategic concerns are also important.

While noting the complexity of the issues surrounding the effects of, and reasons for, RTA formation, this paper limits itself 
to quantifying the impact of several regional trading arrangements on the trade flows among participants and with third countries. The remainder of the paper is organized as follows: section II briefly presents the recent trends in regionalism, while section III analyses several South-South RTAs using two methodologies to assess the impact of RTAs - an ex-post gravity model and an ex- ante $\mathrm{CGE}$ analysis. The estimated results of the computable general equilibrium (CGE) simulation are arrived at by using the Global Trade Analysis Project (GTAP) model. The concluding section summarizes the main findings and, on that basis, lists some policy issues that need to be addressed during the process of RTA formation. 


\section{RECENT ISSUES IN RTA FORMATION}

Irrespective of the catchphrase used to characterize it, regionalism has intensified over the last decade. RTAs are more numerous than ever and at the moment there seems to be little, if anything, that can stop this trend. It is most visible with regard to bilateral trade agreements notified to the WTO in the last decade. Figure 1 shows the number of notified RTAs, in force each year since the inception of the GATT. As can be seen, the number of RTAs in force remained almost constant between 1978 and 1991 . Since then, the number of notified RTAs in force has risen rapidly, increasing from 42 in 1991 to 87 in 1998, an increase of 107 per cent. By July 2000, 172 regional agreements were in force (WTO, 2000).
Furthermore, the integration process has moved beyond the regional level to become interregional. New intercontinental integration projects with a potentially significant impact on global trade and investment have been proliferating. APEC economies have agreed to achieve free and open trade and investment by 2010 (2020 in the case of developing countries) (UNESCAP, 1998). In the Western Hemisphere, the Free Trade Area of the Americas (FTAA), comprising 34 countries from Canada to Argentina, is in the making, with negotiations to be completed no later than 2005 (Aninat, 1996; Devlin, Estevadeordal and Jorge, 1999). The EU's widening of integration has extended to

Figure 1. Number of notified RTAs, by year of entry into force

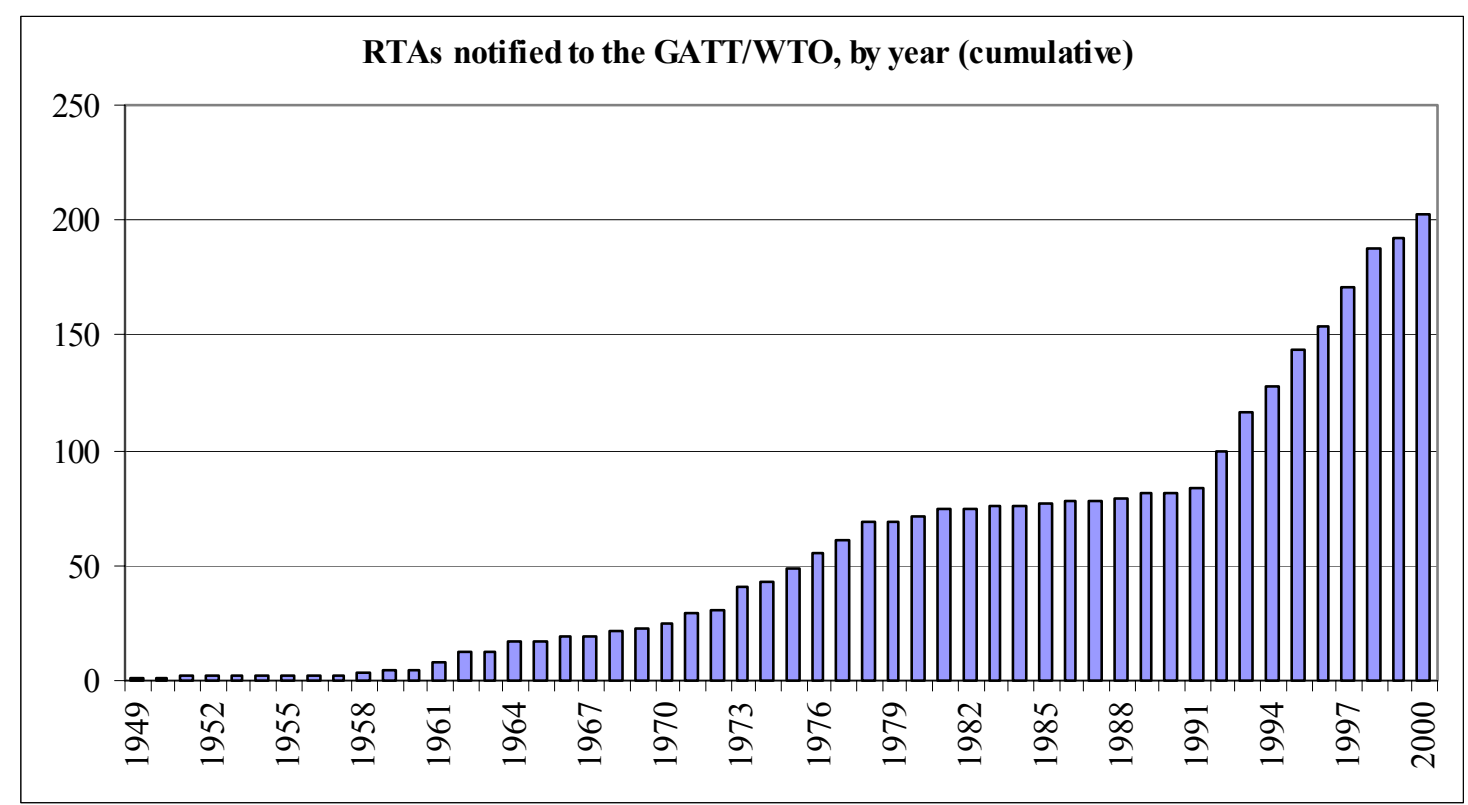

Source: WTO (2002). 
countries and regions outside Europe. Also, discussions have been revived regarding freer transatlantic trade between the EU and United States (European Commission, 1999).

Another feature of the current wave of regionalism that needs to be underlined relates to the role played by the EU as a major driving force behind the move towards regionalism. EU commercial policy has pursued the formation of RTAs with countries from a number of major geographical areas: the EFTA countries, the ACP countries, the Mediterranean region, and the Baltic and Central and Eastern European countries. Indeed, out of the 93 agreements notified under GATT Article XXIV up to May 2000, the EU was a party to 28. As part of the EU's broad commercial policy, these EU agreements are tailored to the different interests of the EU in those regions, and for much of the time the EU has adopted a regionally consistent approach, promoting the subsequent RTA formation among countries in the region. This process gave birth to a significant number of $E U$-generated $R T A s$, around 30 other agreements being formed between countries with which the EU already has bilateral arrangements: EastCentral European and Baltic countries, Israel, Turkey, and countries in North Africa and the Mediterranean basin (see figure 2). These agreements broadly have the same characteristics as the EU model itself. The EU generated these agreements through both political declarations (see, for instance, the Barcelona Declaration, and the Presidency Conclusions of the Cannes European Council of June 1995) and economic incentives (regional financial support and capacity building), or through trade incentives (the most important being the pan-European cumulation of origin). The EU has placed great emphasis on the pan-European system of cumulation of origin as a way of encouraging trade in intermediate goods and services among its associate countries, thereby making use of potential complementarities among them. This has effectively created in practice if not in law a single European free trade agreement (FTA).

Lastly, in an indirect manner, the success of the EU's integration process has tempted many developing countries to follow its integration project of establishing a common market and an economic union. The result was the formation of several regional integration schemes, especially in Africa and Latin America, that aimed at similar integration objectives, with varying degrees of success. Already more than 50 per cent of the agreements notified follow the EU model, with the agreements between the EU associate countries being in many respects similar to the agreements between the EU and associate countries. ${ }^{7}$

Virtually all WTO Members are parties of at least one RTA, and many are parties of two or more. Bilateral FTAs among countries belonging to the same broad geographical region continued to predominate. However, newly formed RTAs and those at various stages of negotiation in 2001 show that, in addition to RTAs among countries belonging to the same geographical region, bilateral FTAs between countries belonging to different continents are becoming more prominent (figure 2).

Equally new is the increasing number of agreements involving developing and developed countries. Among such mixed agreements, a major development in 2001 was the formal launch of negotiations on a Free Trade Agreement of the Americas (FTAA), linking 34 countries from preexisting subregional groupings, including NAFTA (which is in its last stage of implementation), MERCOSUR, CARICOM and CACM, as well as the dense network of bilateral free trade. Other interregional and intercontinental trade integration initiatives are also under way. The most notable ones are the negotiations on freetrade agreements between the European Union, on the one hand, and Chile and MERCOSUR, 


\section{Figure 2. Classifying RTAs at various stages of negotiation or implementation during 2001}

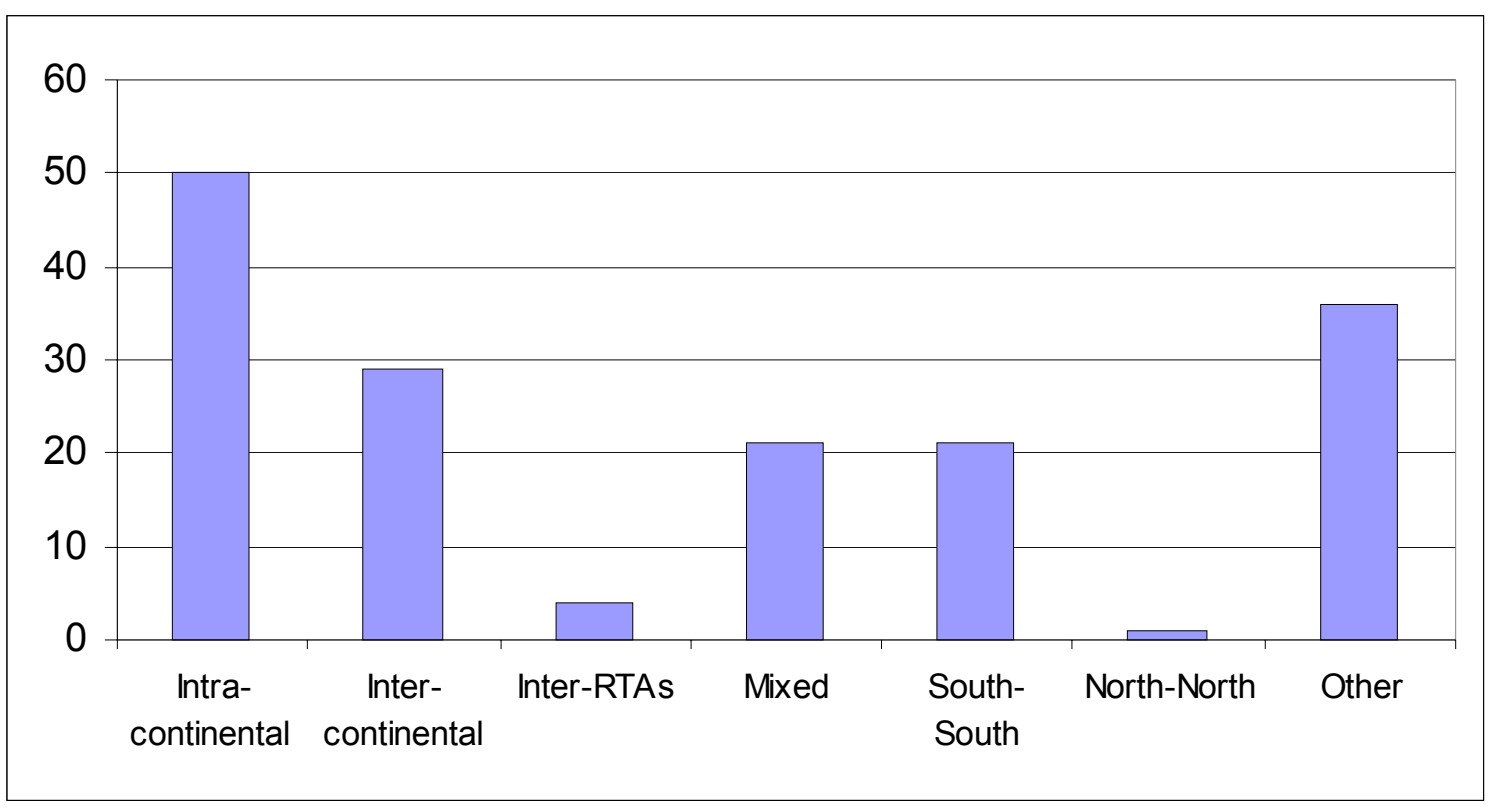

Note: Intra-continental refer to agreements between countries belonging to the same geographical region; Inter-continental counts the number of new RTAs between countries situated on different continents; Inter-RTAs refer to those trading arrangements between two or more existing RTAs; Mixed RTAs refer to agreements involving developing and developed countries, while South-South and North-North refer to developing-only and developed-only agreements, respectively. Other RTAs, refer to RTAs involving one or more transition economies.

respectively, on the other hand. In Asia, a major development is the increasing number of RTAs planned or under negotiation, in particular those involving Japan, which until 2001 was among the few WTO members not party to any RTA. Japan, like the Republic of Korea, has shifted its long-standing policy of multilateral-only trade liberalization to initiate negotiations on an FTA with Singapore, and has formed a study group to consider the feasibility of FTAs with the Republic of Korea and Mexico. Singapore is also very active in forging preferential bilateral trade links with Australia, Canada and Mexico.

The other prominent examples in the new trend are RTAs involving at least one Latin American country. Some 20 new such agreements are expected. The most active Latin American countries are Chile, which intends to conclude 10 more agreements, followed by Mexico with 6 and MERCOSUR with 4 . It is interesting to observe some emerging hub positions. Chile is the most prominent example in terms of both number and geographical distribution. Mexico is also trying to diversify its RTA links outside the Americas (agreements with the EU, Japan, Singapore and Israel). In addition, since the late 1990s, new proposals for preferential trading arrangements have also begun proliferating in the Asia-Pacific region (see box 1).

Even though only a few of these proposals has been implemented so far, it is evident that several economies in the region are seriously engaged in the development of new preferential trading relationships, while others are actively considering moves in this direction. This includes economies in the 


\section{Box 1. Proposed new RTAs in the Asia-Pacific region}

(1) NAFTA-related: Singapore-United States*, Japan-Mexico, Republic of Korea-Mexico, Singapore-Mexico*, Japan-Canada, Singapore-Canada, P5 (United States, Australia, Singapore, Chile, New Zealand), Australia-United States

(2) Chile-focused: Republic of Korea-Chile, Singapore-Chile, Japan-Chile, New Zealand-Chile, United States-Chile

(3) Western Pacific bilateral RTAs: Singapore-Japan*, Singapore-New Zealand, Singapore-Australia*, Singapore-Republic of Korea, Republic of Korea-Australia, Republic of Korea-New Zealand, Hong Kong (China)-New Zealand

(4) Amalgamation of existing RTAs: AFTA-CER

(5) Potential steps for East Asia: Japan-Republic of Korea, Japan-Republic of Korea-China, ASEANplus-three, China-ASEAN

(6) Western Hemisphere: FTAA*

(7) Europe-related and Transatlantic: Mexico-EU, Singapore-EU, EU-Chile, Singapore-EFTA, EUUnited States

Source: PECC (2001).

Note: * under negotiation; italics refer to agreements signed; and all others are under study or being proposed.

region which were in the past staunchly against the preferential route of trade liberalization, such as Japan and the Republic of Korea.

In a world where regional trade arrangements are so widespread, it is hard to characterize them as "exceptions". Given the current trends, it is becoming increasingly important to understand not only the rationale behind them but also their likely effects on participants and third countries. On the other hand, it has to be said that only relatively few integration schemes among developing countries have effectively achieved their integration objectives. Most RTAs among developing countries are still behind their original schedule. This slow progress in regional integration has led many observers to conclude that significant economic advantages from integration have rarely been reaped in terms of export diversification, increased international competitiveness, more efficient allocation of resources, or significant stimulation of production and investment in the region (Yeats, 1998; Foroutan, 1993; Nogues and Quintanilla, 1993).

Given the importance of this issue and the ambiguity that persists regarding the economic impact of many RTAs among developing countries, the next section of the paper will rely on two widely used methodologies to assess the impact of several South-South agreements on members and third countries. 


\section{METHODOLOGICAL APPROACHES TO THE STUDY OF RTA TRADE EFFECTS}

While the new wave of regionalism has positive institutional and political implications, there are not always clear estimates regarding their economic effects. The reason for this uncertainty is the complexity of many RTAs, but also the multitude of metrics used to assess them from an economic point of view.

For many years, the general opinion was that any economic integration that represents a movement towards freer trade should therefore be beneficial and welfareenhancing. This opinion was only challenged in 1950 when Jacob Viner showed in his Customs Union Issue that the net impact of a regional trade agreement on welfare is uncertain and depends on a number of economic circumstances. This early theoretical and empirical literature that started in the 1950s with Viner's seminal work (Viner, 1950) opened up new ground by advancing the idea that the net welfare effects stemming from the formation of an RTA are ambiguous. ${ }^{8}$ In a simple partial equilibrium model under perfect competition, an RTA will increase the level of trade between members at the expense of less efficient domestic producers (trade creation) but also of more efficient third countries (trade diversion). ${ }^{9}$ The net effect of an RTA on trade (as a proxy for welfare) depends thus on the relative size of these two effects. The issue of the net effect of RTAs on the welfare of the member countries and on the world economy is, therefore, an empirical issue. Moreover, even if there were a clear-cut theoretical answer to the question of the size of the effects, the magnitude of the latter would still be of interest.
Trade creation and diversion effects are estimated empirically in a number of ways. One method that is best suited for expost analyses is based on the gravity model. For ex-ante studies both partial and general equilibrium models are widely used. Despite a number of drawbacks, the partialequilibrium models have the advantage of working at a very disaggregated product level. ${ }^{10}$ Another, more complex approach is based on CGE models that take into account all the intersectoral and international linkages that are affected by changes in trade policies as a result of RTA formation.

In the remainder of this section, the gravity model will be used to analyse ex-post the trade effects of nine RTAs, while the CGE model will be used for an ex-ante analysis of a Framework Agreement on Trade Preferential System (FATPS) among the member States of the Organization of the Islamic Conference (OIC).

\section{A. South-South RTAs: A gravity model- based ex-post assessment}

Prior to the recent wave of global CGE models, the gravity model had to a large extent become the "workhorse" of studies on regionalism (Bayoumi and Eichengreen, 1997). It has been used widely as a baseline model for estimating the impact of a variety of policy issues, such as political blocs, patent rights, regional trading groups and various trade distortions. ${ }^{11}$ There has been widespread use of gravity equations in estimating the trade effects arising from RTA formation, despite the fact that they are often perceived as lacking a strong theoretical 
basis. Most early papers using gravity models were ad hoc rather than being based on theoretical foundations. Despite its use in many early studies of international trade, the equation was considered suspect in that it could not easily be shown to be consistent with the dominant Heckscher-Ohlin model explaining net trade flows in terms of differential factor endowments. Exceptions to this trend include Anderson (1979), Bergstrand (1985), Deardorff (1998), and Feenstra, Markusen and Rose (1998). Anderson (1979) showed that the gravity model could be derived from expenditure share equations, assuming commodities to be distinguished by place of production. Anderson also showed that the model should also, to be fully consistent with the generalized expenditure share model, include remoteness measures in bilateral share equations, as used in this paper. Bergstrand (1985) showed that the gravity model can also be derived from models of trade in differentiated products. Such trade must lie at the core of much of manufacturing trade, given the very large two-way flows of trade in even the most finely disaggregated industry data. Finally, Deardorff (1998) showed that a suitable modelling of transport costs produces the gravity equation as an estimation form even for the HeckscherOhlin model.

Typically, in the case of the gravity model of trade, bilateral trade flows are dependent on the size of the two economies and the distance between them. Thus, the most commonly used version of the gravity model assessing the impact of RTAs is the following: where $X_{i}^{\prime}$ are exports from country $i$ to country $j$ at time $t, Y_{i}^{t}$ and $Y_{j}^{t}$ are the gross domestic product (GDP) of country $i$ and $j$ at time $t$, D is the distance between the capital cities of the two countries, and $\mathrm{e}_{\mathrm{ij}}$ is a random error term usually taken to be normally distributed. It is common to expand the basic gravity model by adding other variables, which are thought to explain the impact of various policy issues on trade flows. In the case of gravity equations used to estimate the impact of regional trade arrangements, dummy variables are added for each RTA under scrutiny. Furthermore, in order to avoid capture by these dummy variables of the impact of other influences on trade, other dummy variables are added for common language and common border. ${ }^{12}$ Thus, the other variables (contig, lang, $R T A_{k}$ ) are dummies for common border, common language and RTA membership, respectively. The coefficients for all these dummy variables are expected to be positive since neighbouring countries or those sharing the same language are assumed to trade more than non-neighbouring countries or countries with different languages.

\section{The model ${ }^{13}$}

A particular specification of the gravity model may be used to assess the trade creation and diversion effects resulting from RTA formation. The model used in this paper is specified in the following:

$$
\log \left(X_{i j}^{t}\right)=c_{0}+c_{1} \log \left(Y_{i}^{t}\right)+c_{2} \log \left(Y_{j}^{t}\right)+c_{3} D_{i j}+c_{4} \text { contig }+c_{5} \text { lang }+c_{6} R T A_{1 k}+e_{i j}
$$


exports $_{\mathrm{xm}}{ }^{\mathrm{t}}=\mathrm{c}_{0}+\mathrm{c}_{1} g d p_{\mathrm{X}}{ }^{\mathrm{t}}+\mathrm{c}_{2} g d p_{\mathrm{M}}{ }^{\mathrm{t}}+\mathrm{c}_{3} g d p p c_{\mathrm{X}}{ }^{\mathrm{t}}+\mathrm{c}_{4} g d p p c_{\mathrm{M}}{ }^{\mathrm{t}}+\mathrm{c}_{5}$ dist $+\mathrm{C}_{6}$ CONTIG $+\mathrm{C}_{7} \mathrm{LANG}+$ $+\mathrm{C}_{8}$ INTRA_AFTA $+\mathrm{C}_{9}$ EXTRA_AFTA $+\mathrm{C}_{10}$ INTRA_AND $+\mathrm{C}_{11}$ EXTRA_AND $+\mathrm{C}_{12}$ INTRA_CARICOM $+\mathrm{C}_{13}$ EXTRA_CARICOM $+\mathrm{C}_{14}$ INTRA_COMESA + $+\mathrm{C}_{15}$ EXTRA_COMESA $+\mathrm{C}_{16}$ INTRA_ECOWAS $+\mathrm{C}_{17}$ EXTRA_ECOWAS $+\mathrm{C}_{18}$ INTRA_EU + $\mathrm{C}_{19}$ EXTRA_EU $+\mathrm{C}_{20}$ INTRA_MERCOSUR $+\mathrm{C}_{21}$ EXTRA_MERCOSUR + $C_{22}$ INTRA_NAFTA_TC $+C_{23}$ EXTRA_NAFTA $+C_{24}$ INTRA_SADC $+C_{25}$ EXTRA_SADC $+a_{i j}$

where all variables in lowercase are expressed in logarithmic form:

exports $\quad$ logarithm of exports from country $\mathrm{X}$ to $\mathrm{M}$ in year $\mathrm{t}$

$\mathrm{C} \quad$ intercept

$g d p_{\mathrm{X}}{ }^{\mathrm{t}} \quad$ logarithm of country's X GDP in year $\mathrm{t}$

$g d p_{\mathrm{M}}{ }^{\mathrm{t}} \quad$ logarithm of country's M GDP in year $\mathrm{t}$

$g d p p c_{\mathrm{X}}{ }^{\mathrm{t}} \quad$ logarithm of country's X GDP per capita in year $\mathrm{t}$

$g d p p c_{\mathrm{M}}{ }^{\mathrm{t}} \quad$ logarithm of country's M GDP per capita in year $\mathrm{t}$

dist logarithm of distance between the capital cities of $\mathrm{X}$ and $\mathrm{M}$

CONTIG dummy variable taking the value of 1 if countries $\mathrm{X}$ and $\mathrm{M}$ share a common border, otherwise being zero

LANG dummy variable taking the value of 1 if countries $\mathrm{X}$ and $\mathrm{M}$ share a common language, otherwise being zero

INTRA_RTA dummy variable taking the value of 1 if countries $X$ and $M$ are part of the RTA, zero otherwise

EXTRA_RTA dummy variable taking the value of 1 if country $M$ is a member of the RTA and X a non-member, zero otherwise.

For the pooled data, two year dummies were added for 1994 and 1998 (Y94, Y98).

The two dummy variables take the value of unity in the following cases: EXTRA_RTA becomes unity if the exporter is a third country and the importer is an RTA member, otherwise it is set equal to zero. INTRA_RTA becomes unity if both partners are RTA members. The two dummy variables can be interpreted jointly in terms of trade creation and diversion effects. ${ }^{14}$

Thus, if third country exports increase as a result of RTA formation (EXTRA_RTA $>0)$ this suggests a trade creation and expansion effect, if INTRA_RTA is positive. This interpretation is in line with Vinerian theory, since the increase in both intra- and extra-trade does not lend support to the existence of trade diversion. If only EXTRA_RTA is positive and INTRA_RTA is negative, there is only a trade expansion effect. If INTRA_RTA $>0$, a negative sign for EXTRA_RTA would suggest evidence in favour of trade diversion. If both variables are negative, the effect is trade contraction (table 1).

Table 1. Interpreting RTA dummy variables

\begin{tabular}{|c|c|c|c|}
\hline \multirow{2}{*}{ Coefficient } & \multicolumn{3}{|c|}{ EXTRA_RTA } \\
\hline \multirow{2}{*}{ INTRA_RTA } & Sign & + & - \\
\cline { 2 - 4 } & + & $\begin{array}{c}\text { Trade creation and } \\
\text { trade expansion }\end{array}$ & Trade diversion \\
\cline { 2 - 4 } & - & Trade expansion & Trade contraction \\
\hline
\end{tabular}


Such RTA dummy variables are included for the following major regional trading blocs: the EU, NAFTA, MERCOSUR, the Andean Community, CARICOM, SADC, COMESA, CER, AFTA and ECOWAS. The results of the SouthSouth RTAs included in this analysis are presented below.

\section{The results}

Even though AFTA was less in operation during the sample period than other RTAs, AFTA trade creation is well above unity in all years, a fact which suggests that AFTA countries were trading in 1996 and 1998 over four times more (over five times more in 1994) than one would expect, given all the other gravity variables. At the same time, AFTA countries' imports from third countries were also more than four times in 1994, and more than double in 1998, the level of trade between two otherwise comparable non-AFTA countries. The bottom line is that even though progress towards creating AFTA was rather slow among ASEAN countries, there is strong evidence for an outwardoriented trade arrangement. Similarly, CARICOM, COMESA, ECOWAS and SADC all show significant trade creation effects with no evidence of trade diversion and moderate trade expansion effects. For instance, trade between COMESA members was more than twice the level, as a result of the trade creation effect. Trade expansion was also quite significant: for example, COMESA imports from third countries were on average 30 per cent higher than the predicted levels.

On the other hand, the Andean Community, despite its early inception, has lower estimates for both trade creation and diversion than many more recent RTAs. ${ }^{15}$ While intra-Andean trade seemed to be more than double the trade levels between otherwise similar countries, exports from third countries were 23 to 40 per cent lower than those between otherwise similar non-
Andean members. These results suggest that during the period examined there was evidence of trade diversion in the Andean region. Similar results were found for MERCOSUR. In the period 1994-1998, it appears that MERCOSUR more than doubled trade among members and reduced extraregional imports with more than a third of their level, as predicted by all other gravity variables.

In sum, these gravity model estimates of the impact of RTA formation on both intraand extraregional trade are all positive (with the exception of Andean Community and MERCOSUR) and in all cases trade creation effects are higher than trade diversion or expansion effects, which suggests that throughout the period under scrutiny intraRTA trade increased more than trade with non-members as a result of RTA formation.

\section{B. Ex-ante CGE analysis: assessing the impact of the FATPS}

Another methodology that has become standard practice in RTA analysis is the use of computable general equilibrium models to estimate ex-ante the likely impact of an RTA (Francois and Shiells, 1994). Because of the complex nature of RTAs and the interplay between a large array of variables incorporated in these models, CGE models are well suited to analysing the likely consequences of envisaged RTAs. ${ }^{16}$ Recent multi-country CGE models incorporate detailed input-output databases about domestic variables on consumption, savings and production disaggregated at sector and country level. These models also work out the inter-country linkages involved in international trade. Trade data are combined with protection and transportation costs to simulate these fundamental international linkages across countries and regions at sectoral level. ${ }^{17}$ 
Figure 3. Gravity model trade creation and diversion effects

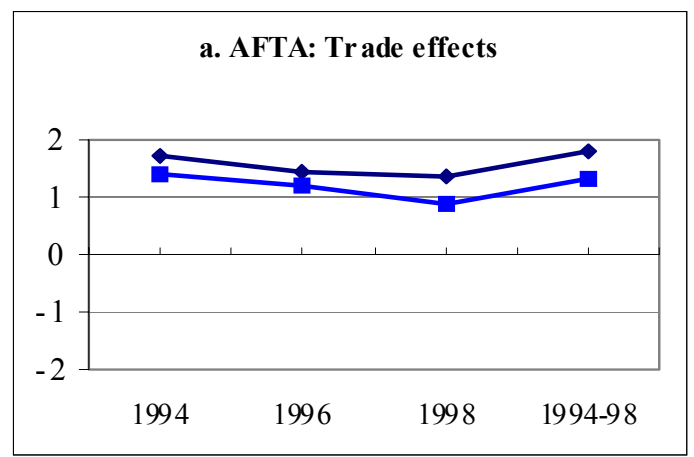

b. Andean Community: Trade effects

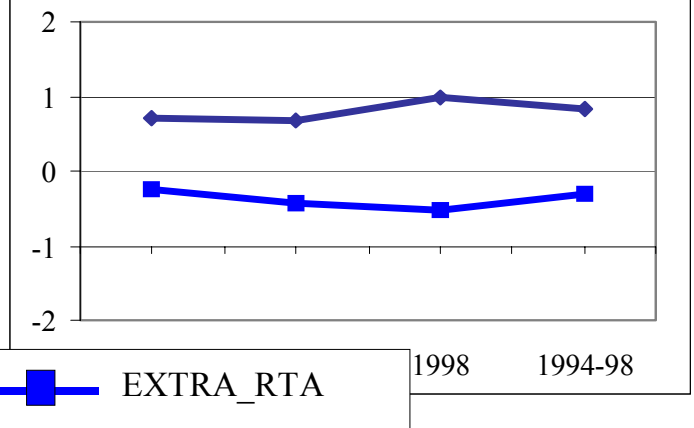

d. Comes a: Trade effects

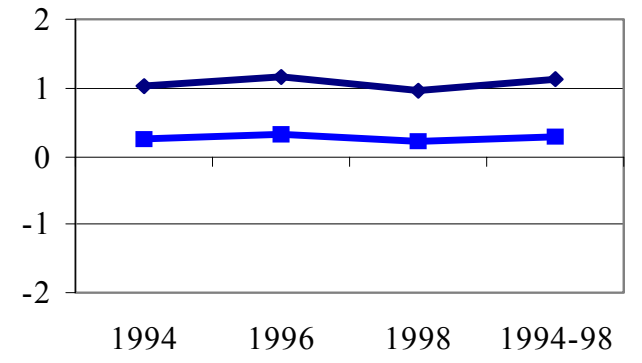

f. MERCOSUR: Trade effects

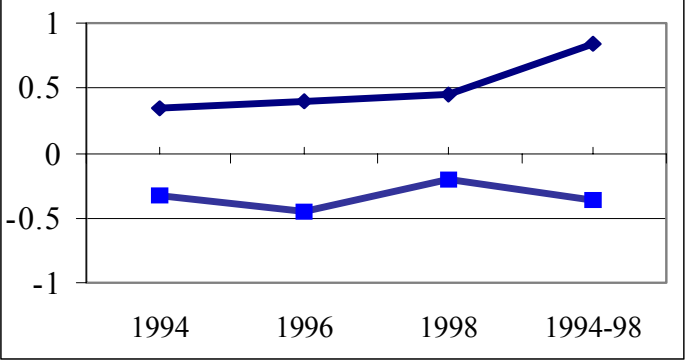

c. Caricom: Trade effects

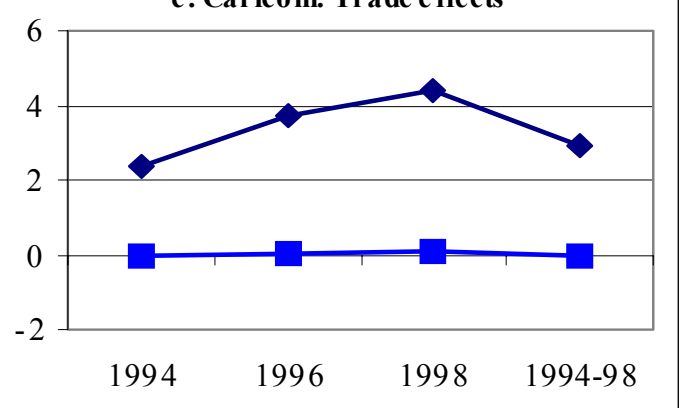

e. ECOWAS : Trade effects

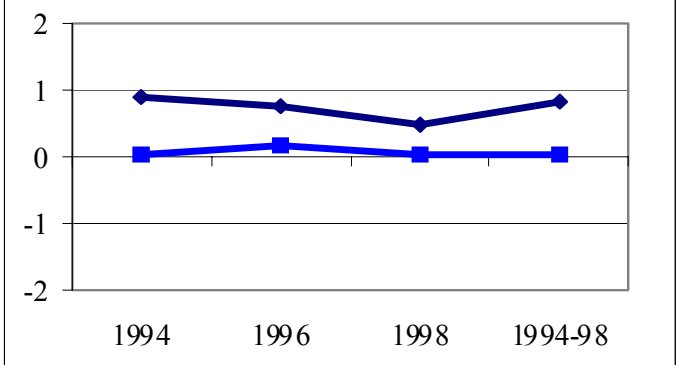

g. SADC: Trade effects

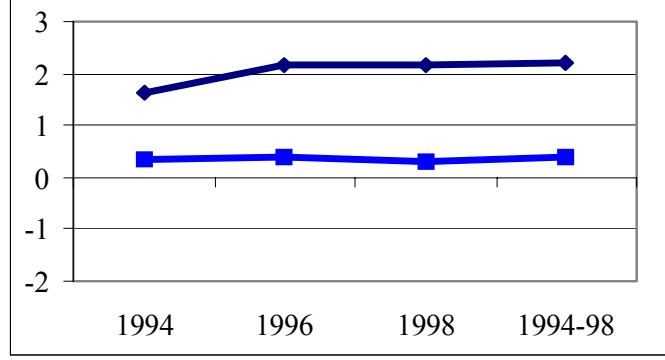

Source: Cernat (2001). 


\section{The current model}

This section focuses on assessing exante the impact of a proposed Framework Agreement on Trade Preferential System (FATPS) among the member countries of the Organization of the Islamic Conference (OIC). Countries that are potential members of FATPS-OIC have already engaged in a variety of trade liberalization initiatives. The OIC member countries have also established and/or joined at least 18 regional economic cooperation schemes in sub-Saharan Africa, North Africa, the Middle East or Asia. Some schemes have been established with other OIC countries. Others include non-OIC partners. ${ }^{18}$ As stated in the text of the FATPS agreement, this new preferential scheme aims to become complementary to these existing regional schemes by promoting trade among OIC members. The main mechanism is the gradual exchange of trade preferences (covering both tariff and non-tariff measures) in all product groups, including agriculture and animal products and industrial goods.

In this section, the formation of the FATPS-OIC is assessed using a multi-country CGE model that makes it possible to analyse ex-ante the impact of RTA formation. The model adopted here consists of 21 linked countries and regions, drawn from those available in the standard Global Trade Analysis Project (GTAP). The country aggregation has been chosen in such a way as to isolate the largest number of potential FATPS members. The original 57 sectors are aggregated into four new sectors (food, other primary products, manufactures and services). The standard GTAP model is a multi-region, static CGE model, with perfect competition and constant returns to scale. Bilateral trade is handled via the Armington assumption (imperfect substitution between foreign suppliers). The trade protection data are those included in the GTAP database version 5 (preliminary version), where 1997 is the base year. ${ }^{19}$
Since the timetable and the actual cuts under the FATPS seem to be flexible and open to negotiations among participants, the only policy scenario simulated in this section involved the removal of all tariffs (including ad valorem equivalents of non-tariff measures, where applicable) among those potential FATPS members that are available in the standard GTAP model as single countries or homogeneous regions (i.e. without non-Islamic countries). As such, tariffs removal is simulated for Bangladesh, Indonesia, Malaysia, Morocco, Mozambique, Turkey and Uganda, as well as 16 other potential FATPS members that are aggregated into the GTAP built-in regional groups of Middle East and North Africa. ${ }^{20}$

\section{Results}

Before the results of the simulation are discussed in detail, some caveats are in order. These empirical results should not be interpreted as "predicting" or "forecasting" since several assumptions behind the analysis were over-simplified to facilitate the undertaking of this policy experiment and the representation of the actual trade arrangement. Obviously, the results are sensitive to changes in these assumptions. Firstly, there is also no attempt to capture the dynamic effects that are often associated with such arrangements, such as increased productive investment flows, changes in technologies or skill upgrading. The focus instead is on understanding the impact of RTA formation on the trade and welfare of both members and non-members. No specific time frame for implementation is envisaged. Consequently, the trade estimates should be interpreted as static, or "before and after" trade effects. ${ }^{21}$ Secondly, in the latest available standard GTAP 5 database used in this experiment, data for all variables refer to 1997 . Therefore, one refinement that could be made to improve the estimates is to construct projections for the year when the FATPS is expected to be fully operational. 
Thirdly, the trade protection data used for this CGE simulation include only the mostfavoured-nation (MFN) treatment of trading partners, no account being taken of the preferential treatment already granted among potential FATPS members within other trading arrangements. In this regard, the current results are overestimates, since once preferential trade is taken into account, both trade creation and trade diversion estimates should be smaller. Furthermore, another improvement in the database would be to update the protection data with the most recent tariff cuts undertaken since 1997 on an MFN basis. This should also reduce the trade diversion effects identified using the current model.
Despite these caveats, the results obtained are still indicative of the likely FTAPS effects. Table 2 reports the percentage changes in exports, terms of trade and welfare for the countries and regions included in the model.

Countries and regions in bold are those that underwent regional liberalization. The results suggest that FATPS has a significant potential for overall trade expansion, increasing the potential intraregional trade of members by as much as 6.15 per cent, in the case of Bangladesh. More modest results are computed for the African countries (Uganda and Mozambique), whose total exports change

Table 2. Full FATPS-OIC scenario: percentage changes in selected variables

\begin{tabular}{lccc}
\hline Region & Exports & Terms of trade & Welfare \\
\hline Australia \& New Zealand & -0.07 & -0.06 & -0.02 \\
China \& Hong Kong (China) & -0.06 & -0.04 & -0.02 \\
Japan & -0.01 & -0.07 & -0.01 \\
Newly industrialized countries & -0.07 & -0.05 & -0.03 \\
Indonesia & $\mathbf{2 . 2 7}$ & $\mathbf{0 . 9 4}$ & $\mathbf{0 . 3 0}$ \\
Malaysia & $\mathbf{1 . 4 2}$ & $\mathbf{0 . 7 0}$ & $\mathbf{0 . 7 8}$ \\
Bangladesh & $\mathbf{6 . 1 5}$ & $\mathbf{- 0 . 8 3}$ & $-\mathbf{0 . 0 8}$ \\
South Asia & -0.28 & -0.17 & -0.04 \\
NAFTA & -0.04 & -0.03 & -0.01 \\
Latin America and Caribbean & -0.09 & -0.06 & -0.02 \\
Western Europe & -0.03 & -0.04 & -0.02 \\
Eastern Europe and & & & \\
Former Soviet Union & 0.00 & -0.04 & -0.02 \\
Turkey & $\mathbf{4 . 9 1}$ & $\mathbf{3 . 9 6}$ & $\mathbf{1 . 1 4}$ \\
Middle East & $\mathbf{2 . 0 8}$ & $\mathbf{- 0 . 2 9}$ & $\mathbf{- 0 . 4 1}$ \\
Morocco & $\mathbf{4 . 2 6}$ & $\mathbf{2 . 1 3}$ & $\mathbf{0 . 8 7}$ \\
North Africa & $\mathbf{3 . 2 5}$ & $\mathbf{- 0 . 1 7}$ & $\mathbf{- 0 . 1 2}$ \\
SACU & -0.02 & -0.02 & -0.01 \\
Sub-Saharan Africa & -0.02 & 0.00 & 0.00 \\
Mozambique & $\mathbf{- 0 . 0 1}$ & $\mathbf{0 . 2 0}$ & $\mathbf{0 . 0 0}$ \\
Uganda & $\mathbf{0 . 9 5}$ & $\mathbf{0 . 6 1}$ & $\mathbf{0 . 0 8}$ \\
Rest of the world & -0.02 & -0.02 & -0.01 \\
\hline
\end{tabular}

Source: GTAP database and author's calculations. Countries in bold are considered FATPS members in the simulation. 
only marginally in the experiment. At the same time, in percentage terms, third countries experience very minor reductions in their overall exports.

With regard to the terms-of-trade changes, the results are more nuanced. While many FATPS potential members witness an improvement in their terms of trade, others (such as Bangladesh, the Middle East and North Africa) may see a moderate deterioration of their terms of trade. For these countries, although the price of exports increases as a result of FATPS formation, the price of imports also increases slightly more than the price of their exports. This effect may be explained by the differences in the sectoral export structure, production and demand factors among FATPS members.

In terms of welfare changes, although virtually all FATPS participants show an increase in exports, not all countries stand to gain under the assumptions underlying the current experiment. Overall, the estimated change in the welfare indicator suggests that the introduction of the FATPS can be a positive development for FATPS countries. For third countries, the welfare losses are almost negligible.

With regard to exports, figure 4 puts together the absolute and percentage changes in total exports as a result of FATPS formation, while figure 5 reports changes in sectoral exports, by FATPS members. Among FATPS members, on the basis of 1997 data, the largest increase in absolute terms in exports occurs for the Middle East, followed by Turkey and North Africa. Since the regional aggregates are different in terms of their economic size, it is also important to assess the percentage changes in exports. Thus, the largest increase in percentage terms

Figure 4. Changes in total exports

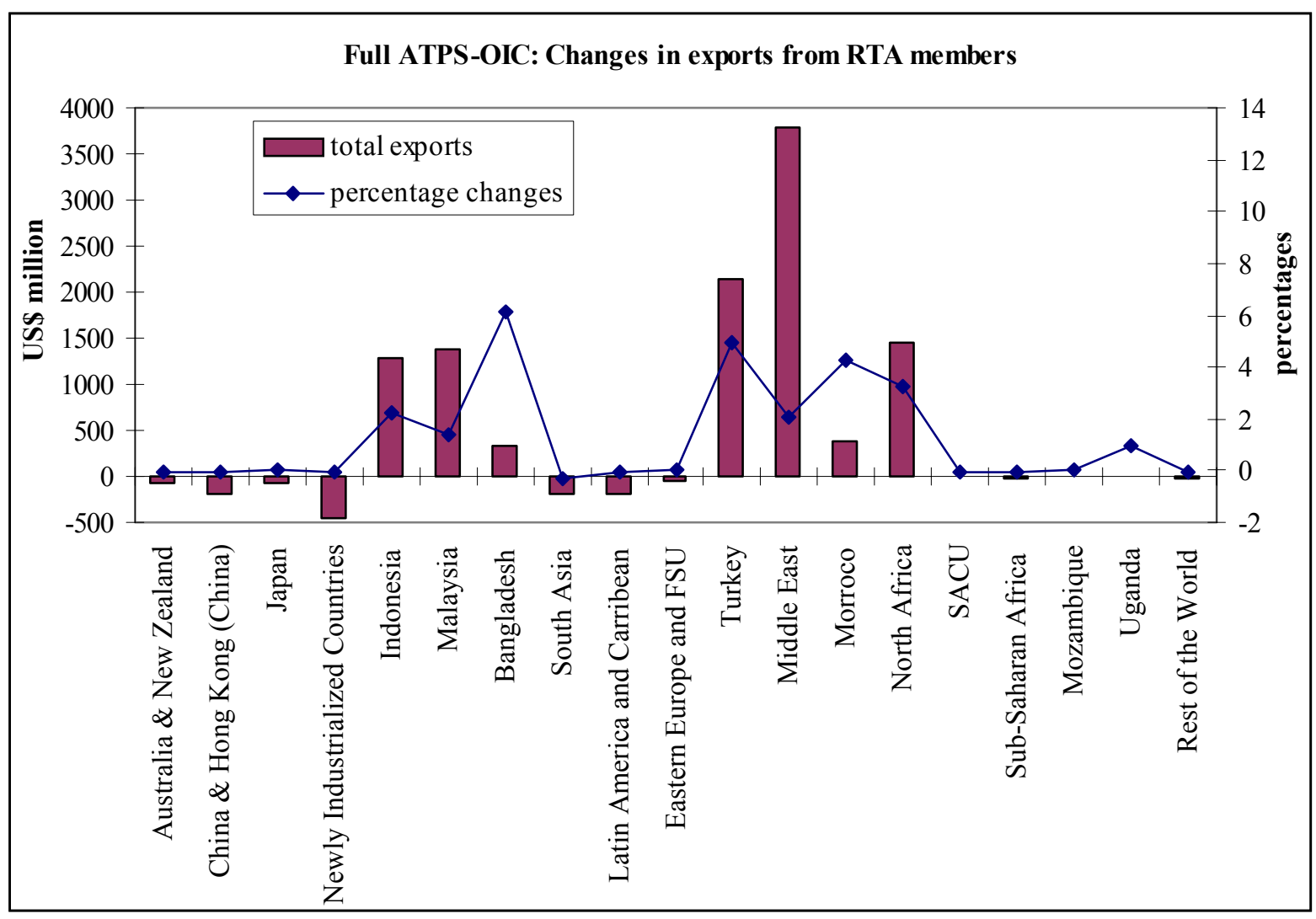

Source: GTAP database and author's calculations. 
Figure 5. Full FATPS liberalization: percentage changes in sectoral exports

Source: GTAP database and author's calculations. See annexes 1 and 2 for a definition of regional and sectoral codes and aggregations.

aecrues to Bangladesh, followed by Turkey.

Finally, figure 6 gives an indication

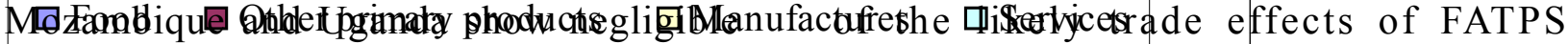
effects both in absolute and in percentage formation, to account for the trade creation 12 erms. At the same time, the reduction in and diversion effects. Trade diversion stands exports from non-mentpers is small in for a decrease in imports of FATPS members $100 \mathrm{~b}$ solute terms, and negli gle in percentage from third countries. Trade creation stands gterms.

60 As for the changes as expected, given the 40 agriculturg as compared 2 sectors, there a drama agridultu al oforts from h sectoral exports
high bariners
ith those in oth
incpease in tot

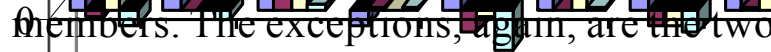
A frican countries included in the experiment -29Mozambique åd'Uganda: Thurkey sęems' to

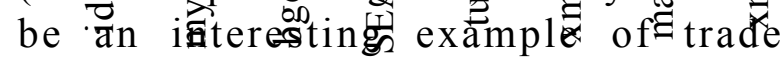
specialization in agriqul turs participants products (more than 100 per cent increase in exports), while witnessing a reduction in all the other sectoral exports. In contrast, in the case of Bangladesh, all sectoral exports show a moderate increase, with agriculture exports increasing by 20 per cent. for an increase in intra-FATPS trade. Trade expansion occurs when imports from nonFATPS members increase as a result of RTA formation. The largest trade creation effect is expected to occur for Turkey, mainly as a result of FATPS agricultural liberalization, followed by Indonesia and Malaysia. The pargest tracte civersion effect is expected to occur with regard to imports from Western $\varangle$ Eungpe, main a s a reduction in food and क agreultufal imports in Middle East countries. While this may seem prima facie a case of trade diversion, it may well be a removal of trade distortions introduced by EU agricultural policies and a move towards more allocative efficiency. Interestingly, in the case of Japan the estimates show an expansionary effect, instead of trade 
diversion. Overall, the data presented in figure 6 confirm the previous findings that the trade creation effects (a $\$ 19$ billion increase in intra-FATPS trade) exceed by far the trade diversion effects (a \$6 billion reduction in FATPS imports from third countries), even though only static effects are considered.

Figure 6. Full FATPS-OIC scenario: trade effects

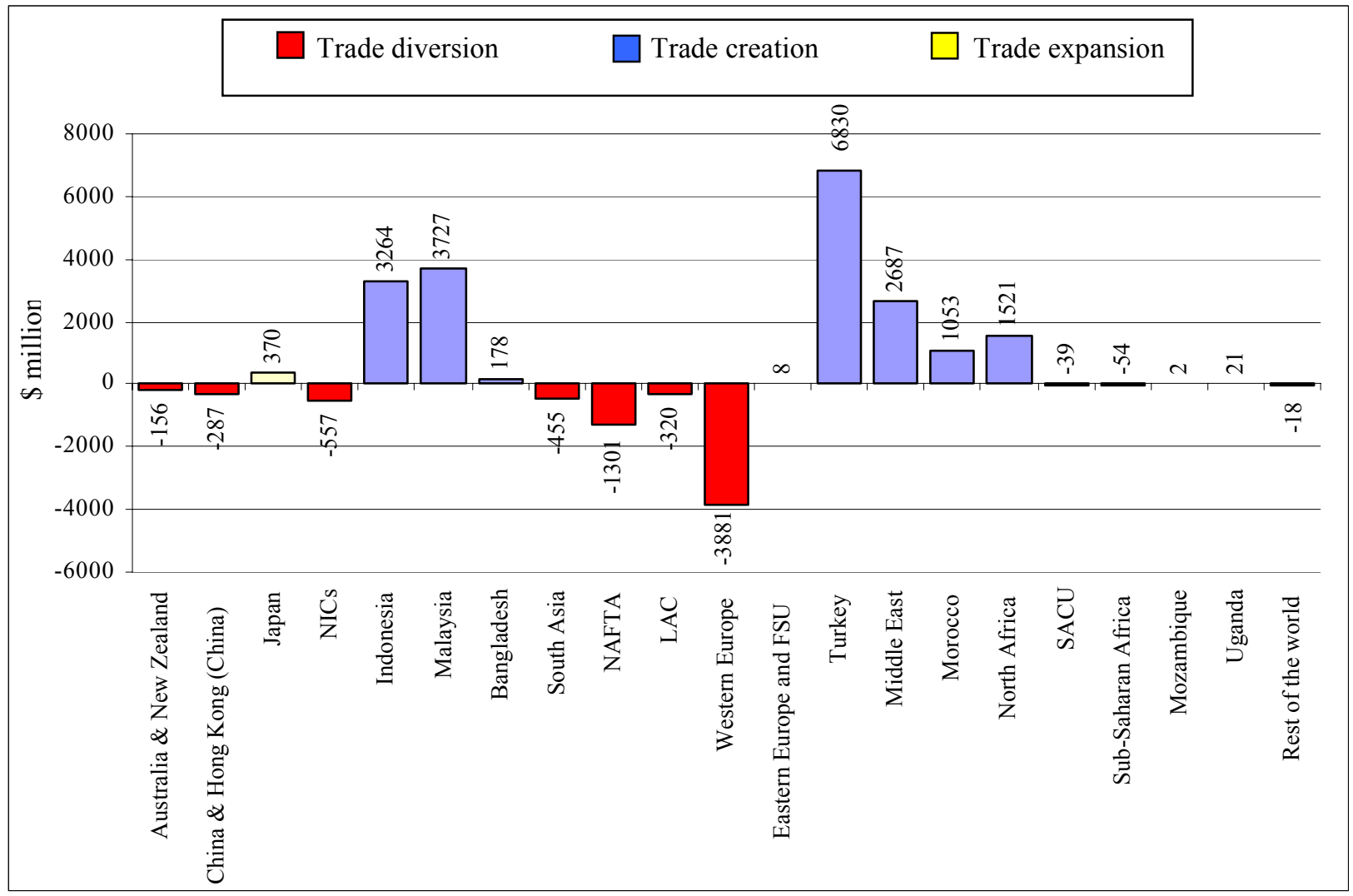

Source: GTAP database and author's calculations. 


\section{CONCLUSIONS}

Recent data show a rapid increase in RTA formation. Although the motivation is often unclear, political as well as economic factors are very important. Therefore, a priori there is no clear indication as to the expected economic effects and the paper used two different methodologies (the gravity model and CGE analysis) to examine the possible trade effects of several South-South RTAs. Owing to the differences in assumptions and methods, the results of each methodology do not easily lend themselves to comparison. However, several similar conclusions emerged from both exercises.

The gravity results have shown that with the exception of the Andean Community and MERCOSUR, which seemed to have reduced trade with non-members, the other South-South RTAs examined are not only trade-creating but also trade-expanding, increasing overall trade, even with third countries, sometimes quite significantly. In the case of FATPS, the ex-ante static CGE results suggest that, despite some potential for trade diversion, the net effect is trade creation.

Although the methodologies used in this paper need further refinement, the findings suggest that regional integration among developing countries is overall net trade-creating and can act as a practical instrument for the gradual integration of developing countries into the global economy. Furthermore, beyond these economic effects, RTAs are very much part of a larger framework for regional cooperation aimed at promoting regional stability, sound and coordinated economic policies and a better regional economic infrastructure. Although difficult to quantify, all these improvements may have a number of positive spillover effects that should be taken into account when assessing the overall impact of South-South RTAs. 


\section{NOTES}

1 For a review of the recent work on RTAs and their welfare effects see, for instance, Pomfret (1997) and DeRosa (1998).

2 In Bhagwati's view, such a patchwork of bilateral, regional and interregional agreements places serious strains upon the coherent functioning of the multilateral trading system, as trade flows are governed by different discriminatory rules.

3 The hub-and-spokes literature argues that, rather than producing an amorphous "spaghetti bowl" regionalism with no clear structure, large developed economies will become hubs for different networks of regional agreements. The spokes are linked to the hub by RTAs in which the hub generally sets the terms and conditions of membership.

4 The building vs. stumbling blocks debate was initiated by Bhagwati (1991), who focused on the impact of regionalism on multilateralism. Essentially, the stumbling block camp argued that regional trade blocs may significantly impede the functioning of a nondiscriminatory multilateral trading system and the ultimate goal of free trade.

5 For surveys of the literature on this debate see Bhagwati and Panagariya (1996), Winters (1996) and Laird (1999).

6 In support of the building blocks view, Summers (1991) argued that RTAs speed up global free trade efforts by creating momentum towards liberalization. Baldwin (1993) formalizes this idea in a model where trade bloc expansion induces outside countries to seek RTA membership and thus, via a "domino effect", to global free trade.

7 Apart from the agreements expected under the ACP-EU framework, there are at least six more agreements where the EU is already or is expected to become a member (with Algeria, Chile, Gulf Cooperation Council, Lebanon, MERCOSUR and Mexico). With regard to the EU-generated RTAs, bilateral trade agreements are expected between each EU RTA partner. For instance, there are bilateral FTAs emerging among all Eastern European and Baltic countries and among both of them and the Mediterranean countries.

8 See, for instance, Viner's and Meade's pioneering work in the 1950 s on free trade areas and customs unions (Viner, 1950; Meade, 1955), which has been further elaborated by, among others, Lipsey (1960), Johnson (1965) and Balassa (1975). For a review of early empirical measurements of trade creation and diversion effects see, for instance, Corden (1975).

9 The trade creation effect is equal to the increase in imports from the partner country at the expense of domestic producers and the post-RTA imports, which were not previously imported. The trade diversion effect resulting from the regional integration arrangement is equal to the initial imports from third countries that are displaced by intra-RTA imports.

10 For a description of an advanced partial equilibrium model, see Laird and Yeats (1986).

11 In addition to international trade flows, gravity models have achieved empirical success in explaining various types of interregional and international flows, including labour migration and commuting.

12 Apart from these dummy variables, other exogenous regressors used are dummies for wars, conflicts, natural catastrophes, and so forth. Krueger (1999) also includes a dummy for remoteness to take into account the fact 
that some countries are further away from most of their trading partners than other countries. Gilbert, Scollay and Bora (2001) add also openness.

13 This section is based on Cernat (2001), where the model and the dataset are discussed at length.

14 It should be noted that trade creation effects refer to gross trade creation, as defined by Balassa (1967). For further details about the construction and interpretation of these dummy variables, see Cernat (2001).

15 Other authors found weaker results for the Andean group in earlier periods. Frankel (1997), for instance, found negative and insignificant trade creation coefficients for 1960s and 1970s and positive trade creation in 1992.

16 For a good survey of the vast empirical work using multi-country CGE models see Robinson and Thierfelder (1999), who review over 70 CGE studies on RTAs.

17 Further refinements were made when dynamic effects were incorporated into the static approach to regional integration. The dynamic effects resulting from regional integration usually cited are those factors introduced by the new trade theory and relate to investment, technological change, competition and scale effects, etc. Both the EU project and NAFTA have been justified on economies of scale that allowed RTA members to increase not only their intraregional exports but also their trade with the rest of the world. Owen (1983), for instance, estimated empirically significant scale effects for some manufacturing sectors as a result of EC integration.

18 For a detailed synopsis of all these arrangements among or including OIC members see SESRTCIC (2000).

19 For a full description of the GTAP model and database, as well as a series of applications of the model, see Hertel (1997).

20 Other OIC members are included in the model, but since they are aggregated together with many other non-OIC members in the built-in GTAP regional groups, they could not be included as potential FATPS members in the policy experiment.

21 When dynamic effects are taken into account, the positive impact of an RTA is generally higher. 
Annex 1. GTAP regional codes and their definition

\begin{tabular}{|c|c|c|}
\hline $\begin{array}{l}\text { GTAP } \\
\text { codes }\end{array}$ & NAME & Definition \\
\hline ausnz & Australia \& New Zealand & Australia, New Zealand \\
\hline chn & China \& Hong Kong (China) & China, Hong Kong (China) \\
\hline jpn & Japan & Japan \\
\hline NICs & Newly industrialized countries & $\begin{array}{l}\text { Republic of Korea, Taiwan Province of China, Philippines, } \\
\text { Singapore, Thailand, Viet Nam }\end{array}$ \\
\hline idn & Indonesia & Indonesia \\
\hline mys & Malaysia & Malaysia \\
\hline bgd & Bangladesh & Bangladesh \\
\hline SEA & South Asia & India, Sri Lanka, Bhutan, Maldives, Nepal, Pakistan \\
\hline NAFTA & NAFTA & Canada, United States, Mexico \\
\hline LAC & Latin America and Caribbean & Latin and Central America, and Caribbean countries \\
\hline WE & Western Europe & Western Europe (European Union and EFTA countries) \\
\hline EE & Eastern Europe and FSU & $\begin{array}{l}\text { Eastern Europe and FSU (Bulgaria, Czech Republic, Hungary, } \\
\text { Poland, Romania, Slovakia, Slovenia, Armenia, Azerbaijan } \\
\text { Belarus, Estonia, Georgia, Kazakhstan, Kyrgyzstan, Latvia, } \\
\text { Lithuania, Rep. of Moldova, Russian Federation, Tajikistan } \\
\text { Turkmenistan, Ukraine, Uzbekistan) }\end{array}$ \\
\hline tur & Turkey & Turkey \\
\hline xme & Middle East & $\begin{array}{l}\text { Middle East (Bahrain, Islamic Rep. of Iran, Iraq, Israel, } \\
\text { Jordan, Kuwait, Lebanon, Oman, Qatar, Saudi Arabia, Syrian } \\
\text { Arab Republic, United Arab Emirates, Yemen, Yemen }\end{array}$ \\
\hline mar & Morocco & Morocco \\
\hline xnf & North Africa & $\begin{array}{l}\text { Other North Africa: Algeria, Egypt, Libyan Arab Jamahiriya, } \\
\text { Tunisia }\end{array}$ \\
\hline SACU & SACU & Botswana, Lesotho, Namibia, South Africa, Swaziland \\
\hline SSA & Sub-Saharan Africa & $\begin{array}{l}\text { Sub-Saharan Africa (Angola, Benin, Burkina Faso, Burundi, } \\
\text { Cameroon, Cape Verde, Central African Republic, Chad } \\
\text { Comoros, Congo, Côte d'Ivoire, Djibouti, Equatorial Guinea, } \\
\text { Eritrea, Ethiopia, Gabon, Gambia, Ghana, Guinea, Guinea- } \\
\text { Bissau, Kenya, Liberia, Madagascar, Malawi, Mali, Mauritania, } \\
\text { Mauritius, Mayotte, Niger, Nigeria, Rwanda, Sao Tome and } \\
\text { Principe, Senegal, Seychelles, Sierra Leone, Somalia, Sudan } \\
\text { Togo, United Rep. of Tanzania, Zaire, Zambia, Zimbabwe } \\
\end{array}$ \\
\hline moz & Mozambique & Mozambique \\
\hline uga & Uganda & Uganda \\
\hline Xrw & Rest of the world & $\begin{array}{l}\text { Rest of the world (Afghanistan, Albania, Andorra, Bermuda, } \\
\text { Bosnia and Herzegovina, British Indian Ocean Territories, Brunei } \\
\text { Darussalam, Burma, Cambodia, Christmas Island, Cocos } \\
\text { (Keeling) Islands, Cook Islands, Croatia, Cyprus, Dem. People's } \\
\text { Rep. of Korea, Falkland Islands, Faroe Islands, Fiji, French } \\
\text { Polynesia, Gibraltar, Greenland, Johnston Island, Kiribati, Lao } \\
\text { People's Dem. Rep., Macao (China), Former Yugoslav Rep. of } \\
\text { Macedonia, Malta, Marshall Islands, FS Micronesia, Mongolia, } \\
\text { Nauru, New Caledonia, Niue, Palau, Papua New Guinea, Pitcairn } \\
\text { Islands, Saint Helena, Solomon Islands, Tokelau, Tonga, Tuvalu, } \\
\text { Vanuatu, Wake Island, Wallis and Futuna Isl., Western Samoa, } \\
\text { Yugoslavia, French Guiana, Guadeloupe, Holy See, Martinique, } \\
\text { Monaco, Reunion, Saint Pierre and Miquelon, San Marino) }\end{array}$ \\
\hline
\end{tabular}

Note: Countries in bold are OIC members, and potential members of the FATPS-OIC. Groups in bold are considered to be FATPS-OIC members in the CGE simulations. 


\section{Annex 2. GTAP: Sectoral aggregation}

\section{Food:}

Paddy rice, Wheat, Cereal grains, Vegetables, fruit, nuts, Oil seeds, Sugar cane, sugar beet, Plant based fibres, Other crops, Bovine cattle, sheep and goats, horses, Animal products, Raw milk, Wool silk-worm cocoons, Bovine cattle, sheep and goat, horse meat products, Other meat products, Vegetable oils and fats, Dairy products, Processed rice, Sugar, Other food products, Beverages and tobacco products.

\section{Other primary products:}

Forestry, Fishing, Coal, Oil, Gas, Minerals.

\section{Manufactures:}

Textiles, Wearing apparel, Leather products, Wood products, Paper products, publishing, Petroleum, coal products, Chemical, rubber, plastic products, Other mineral products, Ferrous metals, Other metals, Metal products, Motor vehicles and parts, Other transport equipment, Electronic equipment, Other machinery and equipment, Other manufactures.

\section{Services:}

Electricity, Gas manufacture, distribution, Water, Construction trade, transport, Financial, business, recreational services, Public administration and defence, education, health, Dwellings and Services. 


\section{REFERENCES}

Anderson, J. (1979). “A theoretical foundation for the gravity equation", American Economic Review, 69 (1): 106-116.

Aninat, A. (1996). Large Economic Spaces: Options for Latin America and the Caribbean, study prepared for the Seminar on Regional Economic Arrangements and Their Relationship with the Multilateral Trading System, Geneva, UNCTAD.

Balassa, B. (1967). "Trade creation and trade diversion in the European Common Market", Economic Journal, 77 (305): 1-21.

Balassa, B. (1975). European Economic Integration, Amsterdam, North Holland.

Baldwin, R. (1993). “A domino theory of regionalism”, NBER Working Paper No. W4465, New York, National Bureau of Economic Research.

Bayoumi, T. and B. Eichengreen (1997). "Is regionalism simply a diversion? Evidence from the EU and EFTA", in T. Ito and A. Kreuger (eds.), Regionalism versus Multilateral Trade Arrangements, Chicago, University of Chicago Press.

Bergstrand, J. H. (1985). "The gravity equation in international trade: Some microeconomic foundations and empirical evidence", Review of Economics and Statistics, 67: 474-481.

Bhagwati, J. (1991). The World Trading System at Risk, Princeton, NJ., Princeton University Press.

Bhagwati, J. and A. Panagariya (eds.) (1996). The Economics of Preferential Trade Agreements, Washington, DC, AEI Press.

Cernat, L. (2001). "Assessing regional trade arrangements: Are South-South RTAs more trade diverting?”, UNCTAD Policy Issues in International Trade and Commodities Study Series No. 16, Sales No. E.01.II.D.32, New York and Geneva, United Nations.

Corden, W.M. (1975). "The costs and consequences of protection: A survey of empirical work", in P.B. Kenen (ed.), International Trade and Finance: Frontiers for Research, Cambridge, Cambridge University Press, 51-91.

Deardorff, A. (1998). "Determinants of bilateral trade: Does gravity work in a neoclassical world?", in J. A. Frankel (ed.), The Regionalization of the World Economy, Chicago, University of Chicago Press.

DeRosa, D. (1998). Regional integration agreements: Static economic theory, quantitative findings, and policy guidelines, World Bank, mimeo. 
Devlin, R., G. Estevadeordal and L. Jorge (1999). “The FTAA: Some longer term issues”, Intal ITD Occasional Paper No. 5, Buenos Aires.

European Commission (1999). Report On United States Barriers To Trade And Investment, Brussels.

Feenstra, R., J.A. Markusen and A. Rose (1998). "Understanding the home market effect and the gravity equation: The role of differentiating goods", NBER Working Paper No. W6804,

New York, National Bureau of Economic Research.

Foroutan F. (1993). "Regional integration in SSA: Past experience and future prospects", in J. de Melo and A. Panagariya (eds.), New Dimensions in Regional Integration, Cambridge, Cambridge University Press.

Francois, J. and C. Shiells (1994). Modelling Trade Policy: Applied General Equilibrium Assessments of North American Free Trade, Cambridge, Cambridge University Press.

Frankel, J.A. (1997). Regional Trading Blocs in the World Economic System, Washington, DC, Institute for International Economics.

Gilbert, J., R. Scollay and B. Bora (2001). "Assessing regional trade arrangements in the Asia Pacific", UNCTAD Policy Issues in International Trade and Commodities, Study Series No. 15, Sales No. E.01.II.D.21, Geneva and New York, United Nations.

Hertel, T. W. (1997). Global Trade Analysis: Modelling and Applications, Cambridge, Cambridge University Press.

Johnson, H.G. (1965). "An economic theory of protectionism, tariff bargaining and the formation of customs unions, Journal of Political Economy, 73: 256-283.

Krueger, A. O. (1999). "Trade creation and trade diversion under NAFTA", NBER Working Paper No. 7429, New York, National Bureau of Economic Research.

Laird, S. (1999). "Regional trade agreements: Dangerous liaisons?”, World Economy, 22 (9): 1179-1200.

Laird, S. and A. Yeats (1986). The UNCTAD trade policy model: a note on methodology, data and uses, Geneva, mimeo.

Lipsey, R. (1960). "The theory of customs unions: A general equilibrium analysis', Economic Journal, 70: 496-513.

Meade, J.E. (1955). The Theory of Customs Unions, Amsterdam, North Holland.

Nogues, J.J. and R. Quintanilla (1993). "Latin America's integration and the multilateral trading system", in J. de Melo and A. Panagariya (eds.), New Dimensions in Regional Integration, Cambridge, Cambridge University Press. 
Owen, N. (1983). Economies of Scale, Competitiveness, and Trade Patterns within the European Community, Oxford, Clarendon Press.

Pomfret, R. (1997). The Economics of Regional Trading Arrangements, Oxford, Clarendon Press.

Robinson, S. and K. Thierfelder (1999). "Trade liberalization and regional integration: The search for large numbers", IFPRI TMD Discussion Paper No. 34, International Food Policy Research Institute, Washington, DC.

Scollay, R. (2001). "RTA trends in the APEC region", Paper presented at Regional Trading Arrangements: Stocktake and Next Steps Trade Policy Forum, Bangkok, 12-13 June.

Statistical, Economic and Social Research and Training Centre for the Islamic Countries (SESRTCIC) (2000). "Regional economic groupings of the OIC countries", Journal of Economic Cooperation, 21 (2): 67-114.

Summers, L. (1991). "Regionalism and the World Trade System", in Policy Implications of Trade and Currency Zones, A Symposium, sponsored by the Federal Reserve Bank of Kansas City, Jackson Hole (Wyoming, Federal Reserve Bank of Kansas City), pp. 295302.

United Nations Economic and Social Commission for Asia and the Pacific (UNESCAP) (1998). "Implications of the APEC process for interregional trade and investment flows", Studies in Trade and Investment No. 33, Bangkok, United Nations.

Viner, J. (1950). The Customs Union Issue, New York, Carnegie Endowment for International Peace.

Winters, A. (1996). "Regionalism versus multilateralism”, World Bank, Policy Research Working Paper No.1687, Washington, DC.

Winters, A. (1997). "Regionalism and the rest of the world: The irrelevance of the Kemp-Wan theorem", Oxford Economic Papers, 49 (2): 228-234.

Wonnacott, R. J. (1990). "U.S. hub-and-spoke bilaterals and the multilateral trading system" Toronto, Howe Institute.

Wonnacott, R. J. (1996). "Improving the design of regional free-trade agreements: For better or worse?", American Economic Review, 86 (2): 62-66.

WTO (2000). "Mapping of regional trade agreements: Note by the Secretariat", WTO Document No. WT/REG/W/41, Geneva.

WTO (2002). "Regionalism: facts and figures", available online at http:/www.wto.org/english/ tratop_e/region_e/regfac_e.htm

Yeats, Alexander J. (1998). "What can be expected from African regional trade arrangements? Some empirical evidence", World Bank Working Paper No. 2004, Washington DC, World Bank. 


\section{POLICY ISSUES IN INTERNATIONAL TRADE AND COMMODITIES}

No. 1 Erich Supper, Is there effectively a level playing field for developing country exports?, 2001, 138 p. Sales No. E.00.II.D.22.

No. 2 Arvind Panagariya, E-commerce, WTO and developing countries, 2000, 24 p. Sales No. E.00.II.D.23.

No. 3 Joseph Francois, Assessing the results of general equilibrium studies of multilateral trade negotiations, 2000, 26 p. Sales No. E.00.II.D.24.

No. 4 John Whalley, What can the developing countries infer from the Uruguay Round models for future negotiations?, 2000, 29 p. Sales No. E.00.II.D.25.

No. 5 Susan Teltscher, Tariffs, taxes and electronic commerce: Revenue implications for developing countries, 2000, 57 p. Sales No. E.00.II.D.36.

No. 6 Bijit Bora, Peter J. Lloyd, Mari Pangestu, Industrial policy and the WTO, 2000, 47 p. Sales No. E.00.II.D.26.

No. 7 Emilio J. Medina-Smith, Is the export-led growth hypothesis valid for developing countries? A case study of Costa Rica, 2001, 49 p. Sales No. E.01.II.D.8.

No. 8 Christopher Findlay, Service sector reform and development strategies: Issues and research priorities, 2001, 24 p. Sales No. E.01.II.D.7.

No. 9 Inge Nora Neufeld, Anti-dumping and countervailing procedures - Use or abuse? Implications for developing countries, 2001, 33 p. Sales No. E.01.II.D.6.

No. 10 Robert Scollay, Regional trade agreements and developing countries: The case of the Pacific Islands' proposed free trade agreement, 2001, 45 p. Sales No. E.01.II.D.16.

No. 11 Robert Scollay and John Gilbert, An integrated approach to agricultural trade and development issues: Exploring the welfare and distribution issues, 2001, 43 p. Sales No. E.01.II.D.15.

No. 12 Marc Bacchetta and Bijit Bora, Post-Uruguay round market access barriers for industrial products, 2001, 50 p. Sales No. E.01.II.D.23.

No. 13 Bijit Bora and Inge Nora Neufeld, Tariffs and the East Asian financial crisis, 2001, 30 p. Sales No. E.01.II.D.27. 
No. 14 Bijit Bora, Lucian Cernat, Alessandro Turrini, Duty and Quota-Free Access for LDCs: Further Evidence from CGE Modelling, 2002, 130 p. Sales No. E.01.II.D.22.

No. 15 Bijit Bora, John Gilbert, Robert Scollay, Assessing regional trading arrangements in the Asia-Pacific, 2001, 29 p. Sales No. E.01.II.D.21.

No. 16 Lucian Cernat, Assessing regional trade arrangements: Are South-South RTAs more trade diverting?, 2001, 24 p. Sales No. E.01.II.D.32.

No. 17 Bijit Bora, Trade related investment measures and the WTO: 1995-2001, 2002.

No. 18 Bijit Bora, Aki Kuwahara, Sam Laird, Quantification of non-tariff measures, 2002, 42 p. Sales No. E.02.II.D.8.

No. 19 Greg McGuire, Trade in services - Market access opportunities and the benefits of liberalization for developing economies, 2002, 45 p. Sales No. E.02.II.D.9.

No. 20 Alessandro Turrini, International trade and labour market performance: major findings and open questions, 2002, 30 p. Sales No. E.02.II.D.10.

No. 21 Lucian Cernat, Assessing south-south regional integration: same issues, many metrics, 2003, 32 p. Sales No. E.02.II.D.11.

United Nations publications may be obtained from bookstores and distributors throughout the world. Please consult your bookstore or write to:

\section{United Nations Publications}

All orders from North America, Latin America, the Caribbean and Asia and the Pacific should be sent to:

United Nations Publications

Room DC2-853, 2 UN Plaza

New York, NY 10017, USA

Telephone: (212) 963-8302, Toll Free 1-800-253-9646 (North America only)

Fax: (212) 963-3489

E-mail: publications@un.org

Customers in Europe, Africa and the Middle East should send their orders to:

Section des Ventes et Commercialisation

Bureau E-4, CH-1211

Geneva 10, Switzerland

Telephone: 41 (22) 917-2613/2614

Fax: 41 (22) 917-0027

E-mail: unpubli@unog.ch 


\title{
QUESTIONNAIRE
}

\section{UNCTAD Study Series on \\ POLICY ISSUES IN INTERNATIONAL TRADE AND COMMODITIES}

(Study series no. 21: Assessing South-South Regional Integration:

Same Issues, Many Metrics)

\section{Readership Survey}

Since 1999, the Trade Analysis Branch of the Division on International Trade in Goods and Services, and Commodities of UNCTAD has been carrying out policy-oriented analytical work aimed at improving the understanding of current and emerging issues in international trade of concern to developing countries. In order to improve the quality of the work of the Branch, it would be useful to receive the views of readers on this and other similar publications. It would therefore be greatly appreciated if you could complete the following questionnaire and return to:

\author{
Jenifer Tacardon-Mercado \\ TAB/DITC, Rm. E-8054 \\ United Nations Conference on Trade and Development \\ Palais des Nations \\ CH-1211 Geneva 10, Switzerland
}

1. Name and address of respondent (optional):

2. Which of the following describes your area of work?

Government

Private enterprise institution

International organization

Not-for-profit organization

$\begin{array}{ll}\square \quad & \text { Public enterprise } \\ \square \quad \text { Academic or research } \\ \square \quad \text { Media } \\ \square \quad \text { Other (specify) }\end{array}$

3. In which country do you work?

4. Did you find this publication $\square$ Very useful $\square$ Of some use $\square$ Little use to your work?

5. What is your assessment of the contents of this publication?
$\square$ Excellent
Good
$\square$ Adequate
$\square$ Poor

6. Other comments: 